\title{
Yellow Pumpkin (Cucurbita maxima D.) Extract As Anti-Hypercholesterolemia
}

\author{
Erna Kustiyaningsih, Istianatus Sunnah, Dian Oktianti* \\ Pharmacy Study Program, Faculty of Health Sciences, Universitas Ngudi Waluyo, Ungaran, Jl. Diponegoro No.186, Ngablak, Gedanganak, \\ Ungaran Timur, Semarang, Jawa Tengah 50512.
}

\begin{abstract}
Hyperlipidemia is a risk factor for various diseases, which is still a big problem in Indonesia. Yellow pumpkin (Cucurbita maxima D.) is a plant containing flavonoids and terpenoids, which can be used as an anti-hypercholesterolemic agent. This study aims to analyze the activity and dosage of yellow pumpkin extract, which can be used as an anti-hypercholesterolemic agent to reduce total cholesterol levels comparable to simvastatin by $1.8 \mathrm{mg} / \mathrm{kg} B W /$ day. This research is pure experimental research with a pre and post-test group design approach. The number of samples was 25 male Wistar rats induced by high-fat feed, quail egg yolk: pork oil (2:1) by 5 $\mathrm{ml} / 200 \mathrm{gramBW} /$ day for 7 days. The extract dosage range was 200, $400,600 \mathrm{mg} / \mathrm{kg} \mathrm{BW} /$ day for 7 days. Data were analyzed using One Way ANOVA. The results showed that the administration of yellow pumpkin extract could reduce rats' total blood cholesterol levels with a dose of $600 \mathrm{mg} / \mathrm{kg} \mathrm{BW} /$ day, comparable to simvastatin 1.8 $\mathrm{mg} / \mathrm{kg} \mathrm{BW} / \mathrm{day}$. The secondary metabolites of the extract were flavonoids and terpenoids. Extract of yellow pumpkin (Cucurbita maxima D.) could reduce total blood cholesterol levels of rats. The dose of $600 \mathrm{mg} / \mathrm{kg} \mathrm{BW} /$ day could reduce blood cholesterol levels in rats comparable to simvastatin $1.8 \mathrm{mg} / \mathrm{kg} \mathrm{BW} /$ day.
\end{abstract}

Keywords: Antihypercholesterolemia; Cucurbita maxima $D_{i}$ Flavonoid; Terpenoid

\section{Data of article}

Received : 14 Nov 2020

Reviewed : 19 Dec 2020

Accepted : 22 Feb 2021

DOI

10.18196/jfaps.v1i2.10819

Type of article:

Research

\section{INTRODUCTION}

Hyperlipidemia is a condition of excess lipids or cholesterol metabolism disorders consisting of total cholesterol, triglycerides, $\mathrm{HDL}$, and LDL caused by cholesterol levels in the blood exceeding normal limits ${ }^{1}$. One of the plants that can be used as medicine is yellow pumpkin (Cucurbita maxima D.). Yellow pumpkin flesh contains carbohydrates, protein, fiber, amino acids, tocopherols, and carotenoids ${ }^{2}$. In addition, yellow pumpkin flesh also contains flavonoids 3 . Isoflavone, flavones, and flavanones are a group of flavonoids compounds that can reduce total cholesterol levels ${ }^{4}$. Apart from flavonoids, terpenoids also have an activity to lower total serum cholesterol levels.

\section{METHOD}

This research is purely a pre and post-test group design using the test animals model by taking blood samples before and after

*Corresponding author, e-mail: istianahizna29@gmail.com 
treatment. The pre-test data were taken from the blood sample after induced with high-fat feed, while the post-test data were taken from the blood sample after induced with the extract. The animals were divided into 5 groups, showed in Table (1).

Table 1. Grouping of test animals model

\begin{tabular}{|c|c|}
\hline Groups & Information \\
\hline $\begin{array}{l}\text { Normal } \\
\text { Group } \\
(\mathrm{KN})\end{array}$ & $\begin{array}{l}\text { Animals with standard feeding + } \\
\text { CMC Na }\end{array}$ \\
\hline $\begin{array}{l}\text { Positive } \\
\text { Control (K } \\
+ \text { ) }\end{array}$ & $\begin{array}{l}\text { Animals with standard feeding }+ \\
\text { simvastatin } \\
1.8 \mathrm{mg} / \mathrm{KgBW} / \text { day }\end{array}$ \\
\hline$P_{1}$ & $\begin{array}{l}\text { Animals with Standard feeding }+ \\
\text { extract suspension } 200 \\
\mathrm{mg} / \mathrm{KgBW} / \text { day }\end{array}$ \\
\hline$P_{2}$ & $\begin{array}{l}\text { Animals with Standard feeding }+ \\
\text { extract suspension } 400 \\
\mathrm{mg} / \mathrm{KgBW} / \text { day }\end{array}$ \\
\hline$P_{3}$ & $\begin{array}{l}\text { Animals with Standard feeding } \\
\text { +extract suspension } 600 \\
\mathrm{mg} / \mathrm{KgBW} / \text { day }\end{array}$ \\
\hline
\end{tabular}

\section{Making of Yellow Pumpkin Extract}

Yellow pumpkin (Cucurbita maxima D.) was obtained from the Kopeng area of Semarang Regency, made in simplicia and powdered. The extract was made from 500 grams of the pumpkin flesh, 500 grams of maceration with $96 \%$ ethanol solvent in a 1:10 ratio. Maceration was carried out for 3 days, and re-maceration was done for 2 days. It was then evaporated using a rotary evaporator at a temperature of $60^{\circ} \mathrm{C}$. Phytochemical screening of the extract was carried out. The extract of pumpkin flesh detected flavonoids on TLC with silica GF254 stationary phase, which was then eluted using the mobile phase of $n$ butanol: acetic acid: water (3: 1: 1). As for terpenoids, the mobile phase of chloroform: methanol ( $9: 1)$ was selected. The selection of stationary and mobile phases was based on the polarity and properties of the flavonoids and terpenoids.

\section{Induction of high cholesterol feed}

Hypercholesterolemic feed was made from quail egg yolks and pork oil. The ratio of quail egg yolk: lard was 2:1. High cholesterol feed induction was given to rats for 7 days, and their cholesterol levels were monitored.

\section{Pumpkin extract induction}

The experiment animals in this research were white male rats (Rattus novergicus) aged 2-3 months, with an average weight of 200 grams. The number of samples was 25 male Wistar rats induced with high-fat feed, quail egg yolk: pork oil (2: 1) $5 \mathrm{ml} / 200$ gramBW/day, for 7 days. The extract dosage ranges used were $200 \mathrm{mg} / \mathrm{kg}$ BW/day, $400 \mathrm{mg} / \mathrm{kg}$ BW/day, $600 \mathrm{mg} / \mathrm{kg}$ BW/day for 7 days.

\section{Rat weighing}

Weighing the rats was carried out to determine the effect of high-cholesterol feeding on their body weight.

\section{Data analysis}

The data was in the form of the difference in total blood cholesterol levels in rats from pre and post-test. Data were analyzed using One Way ANOVA.

\section{RESULTS AND DISCUSSION}

Table 1. Identification ethanol-free test

\begin{tabular}{lll}
\hline Samples & Reagents & Result \\
\hline Yellow & $\mathrm{H}_{2} \mathrm{SO}_{4}$ pekat + Not smell \\
pumpkin & $\begin{array}{l}\mathrm{CH}_{3} \mathrm{COOH} \text { was } \\
\text { exter }\end{array}$ \\
extract & heated & \\
\hline Yellow & $\mathrm{K}_{2} \mathrm{CR}_{2} \mathrm{O}_{7}+\mathrm{H}_{2} \mathrm{SO}_{4}$ & No color \\
pumpkin & pekat & change \\
extract & & \\
\hline
\end{tabular}




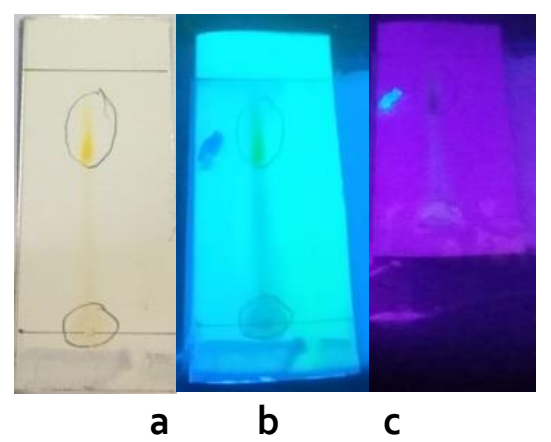

Figure 1. The results of TLC flavonoids (a) observations on visible light, (b) observations at $254 \mathrm{~nm}$ UV after spraying ammonia vapor, (c) observations on UV light $366 \mathrm{~nm}$ after being sprayed with ammonia reagent

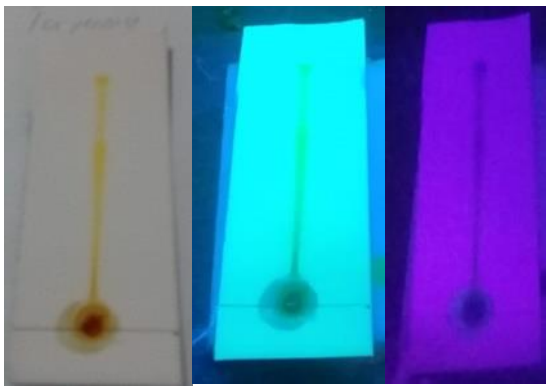

a $\quad$ b $\quad c$

Figure 2. TLC results for the terpenoid class compounds. (a) observing visible light, (b) observing UV light at $254 \mathrm{~nm}$ after being sprayed with LibermanBuchard, (c) observing UV light at $366 \mathrm{~nm}$ after being sprayed with LibermanBuchard

Table 2. Identification of secondary metabolites

\begin{tabular}{|c|c|c|c|c|c|c|c|}
\hline $\begin{array}{l}\text { Secunder } \\
\text { metabolities }\end{array}$ & Reagents & Color spot & $\begin{array}{l}\text { UV } \\
254 \mathrm{~nm}\end{array}$ & $\begin{array}{l}\text { UV } \\
366 \mathrm{~nm}\end{array}$ & $\begin{array}{l}\text { Rf } \\
\text { Standart }\end{array}$ & $\begin{array}{l}\text { Value } \\
\text { Rf }\end{array}$ & $\begin{array}{l}\text { Informati } \\
\text { on }\end{array}$ \\
\hline Flavonoid & Ammonia & $\begin{array}{l}\text { Yellow } \\
(254 \mathrm{~nm}) \\
\text { Blue } \\
(366 \mathrm{~nm})\end{array}$ & Yellow & Blue & $0.54-0.92$ & 0.78 & $(+)$ \\
\hline Terpenoid & $\begin{array}{l}\text { Liberman- } \\
\text { Buchard }\end{array}$ & $\begin{array}{l}\text { Yellow } \\
(254 \mathrm{~nm}) \\
\text { Green - } \\
\text { blue } \\
\text { (366) }\end{array}$ & Yellow & $\begin{array}{l}\text { Green- } \\
\text { blue }\end{array}$ & $0.08-0.96$ & 0.95 & $(+)$ \\
\hline
\end{tabular}

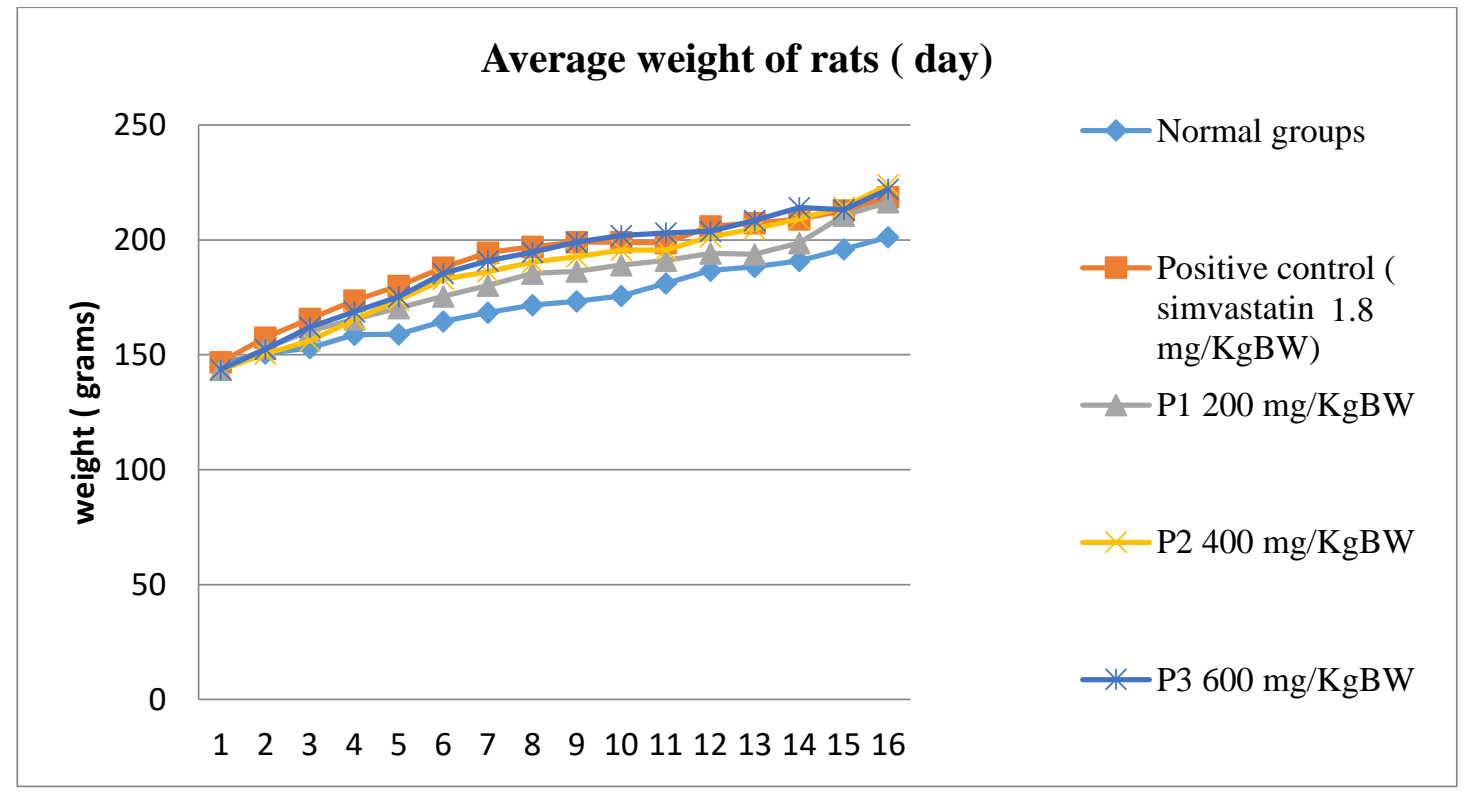

Figure 3. Graph of average weight gain of rats 


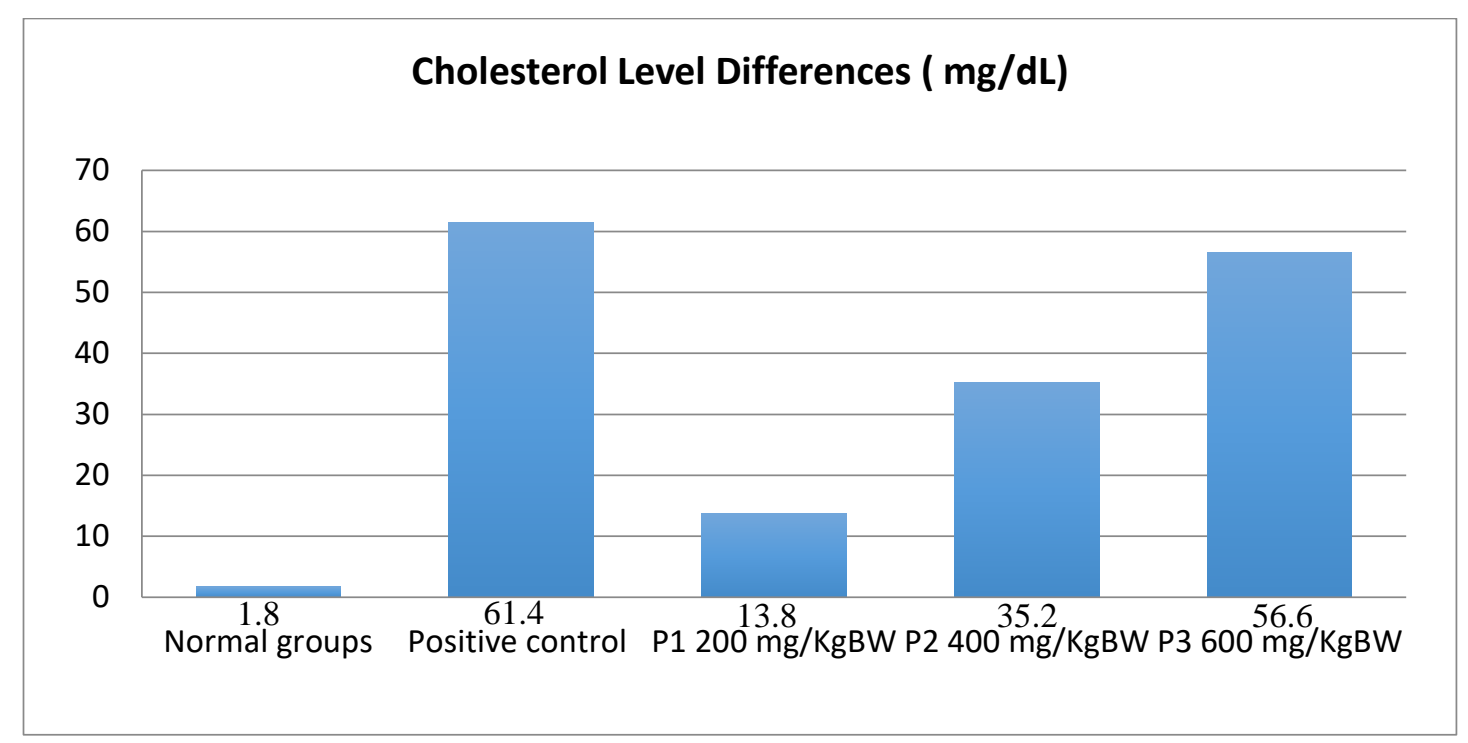

Figure 4. Diagram of Difference in Total Cholesterol Levels Each Group

Table 3. Cholesterol level percentage

\begin{tabular}{ccccc}
\hline Groups & $\begin{array}{c}\text { Cholesterol Level } \\
\text { at Pretest }\end{array}$ & $\begin{array}{c}\text { Cholesterol level at } \\
\text { Post-test }\end{array}$ & $\begin{array}{c}\text { Cholesterol level } \\
\text { Differences }\end{array}$ & $\begin{array}{c}\text { \% decrease } \\
\text { level }\end{array}$ \\
\hline Normal & $113.800 \pm 3.493$ & $112.000 \pm 2.345$ & $1.800 \pm 1.924$ & 1.58 \\
\hline Positive & $186.400 \pm 15.437$ & $125.000 \pm 17.479$ & $61.400 \pm 4.827$ & 32.94 \\
\hline$P_{1}$ & $190.000 \pm 15.572$ & $176.200 \pm 18.606$ & $13.800 \pm 3.421$ & 7.26 \\
\hline$P_{2}$ & $180.800 \pm 22.466$ & $145.600 \pm 23.394$ & $35.200 \pm 4.970$ & 19.47 \\
\hline$P_{3}$ & $182.000 \pm 22.249$ & $125.400 \pm 23.734$ & $56.600 \pm 3.286$ & 31.90 \\
\hline
\end{tabular}

Yellow pumpkin has been widely known for its pharmacological benefits due to its metabolite content in the form of flavonoids and terpenoids. In this study, the pumpkin extraction was carried out to analyze the presence of antihypercholesterolemic activity. The extract was prepared by maceration of Simplicia using ethanol 96\% (1:10). Maceration results obtained a thick reddish-brown extract of 90.149 grams, and the yield was $18.029 \%$. This number has met the requirements of the Indonesian Herbal Pharmacopeia (FHI), which is not less than $10.0 \%$, as the higher the yield value, the greater the extract produced.

\section{Phytochemicals screening}

The thick extract of pumpkin flesh was tested with the ethanol-free test to determine whether there was ethanol content in the extract not to affect the test. The test results showed that the thick extract of pumpkin flesh was free from ethanol as it did not smell ester, and there was no color change ${ }^{5}$ ( Table 1 ).

The result of phytochemical screening showed the presence of secondary metabolite compounds in the form of flavonoids and terpenoids in pumpkin extract (Figure 1 and 2). In Table (2), the result showed a presence of flavonoids with an $\mathrm{Rf}$ value of 0.78 , seen after sprayed 
with ammonia vapor reagent, and an Rf value of 0.95 for terpenoids after sprayed with Liberman Buchard reagent. The mobile phase used to identify flavonoids was n-butanol: acetic acid: water (3:1:1), and the mobile phase for terpenoids used chloroform: methanol (9: 1). The solvent influence determined the metabolite compound extraction due to 'like dissolve like'.

\section{Rat Weighing}

The rats fed high cholesterol in figure (3) showed a higher body weight gain compared to the normal control group. The increase in body weight in the normal group ( $\mathrm{KN}$ ) was $37.43 \%$, the positive group $(\mathrm{K}+$ ) was $48.91 \%$, groups with $200 \mathrm{mg} / \mathrm{kg}$ BW/ day dose $\left(\mathrm{P}_{1}\right)$ was $50.69 \%$, groups with $400 \mathrm{mg} / \mathrm{kg} \mathrm{BW} /$ day dose ( $\left.\mathrm{P}_{2}\right)$ was $56.20 \%$, and groups with $600 \mathrm{mg} / \mathrm{kg} \mathrm{BW/}$ day dose $\left(\mathrm{P}_{3}\right)$ was $54.59 \%$. This result showed that high-fat feeding increased the weight of the test rats higher and faster. During the study, there were differences in the weight gain of the rats. The difference in weight gain occurred as these white rats had genetic differences, causing different treatment responses. Increasing body weight was influenced by diet and lots of fat ${ }^{6}$. Weight gain and increased cholesterol levels in rats were seen during fed fatty foods 7 . In the first stage of the study, the animal models, except the normal control group, were induced with a high cholesterol feed, raw quail egg yolk, and pork oil (2: 1) $5 \mathrm{ml} / 200$ gramBW/day for 7 days to be hypercholesterolemic. Cholesterol levels could increase as quail egg yolks contained very high cholesterol compared to other eggs, which had 3,640 mg/100 grams of eggs, while pork oil contained $200 \mathrm{mg} / 100$ grams of cholesterol. Apart from containing very high cholesterol, quail eggs also had a composition of $31.85 \%$ saturated fatty acids $^{8}$. In addition, pork oil also contained $21 \%$ saturated fatty acids ${ }^{6}$.

\section{Cholesterol Level}

Blood sampling for measuring total cholesterol levels was carried out through the tail, measured using the easy touch device. The advantage of using this tool is that it only requires a small amount of blood sample, is easy to use, and the results are obtained quickly (150 seconds). The results of measuring blood cholesterol levels after feeding high cholesterol were defined as pre-test total cholesterol levels, as showed in figure (4). The results showed a significant increase in the total blood cholesterol levels of rats. It means that the induction of high cholesterol feed using quail egg yolk and lard (2:1) could increase the total cholesterol level of rats, indicated by total cholesterol level $98-148 \mathrm{mg} / \mathrm{dL}^{9}$. Quail has $30.63 \%$ lipid content $^{8}$. Cholesterol levels of the tested animals showed a decrease after treatment with pumpkin extract and simvastatin. The difference between the highest and lowest decreases in a row was: the positive group was $61.40 \mathrm{mg} / \mathrm{dL}$, the $P_{3}$ group was 56.60 $\mathrm{mg} / \mathrm{dL}$, the $P_{2}$ group was $35.20 \mathrm{mg} / \mathrm{dL}$, the $\mathrm{P}_{1}$ group was $13.80 \mathrm{mg} / \mathrm{dL}$, and the normal group was $1.80 \mathrm{mg} / \mathrm{dL}$. The research data obtained in the pre and post test had a fairly large standard deviation, due to the limitations of researchers in controlling food intake in each tested animal.

The results of LSD in the positive control group and the $\mathrm{P}_{3}$ group showed no significant difference $(p=0.062)$. In the positive group, the decrease in total blood cholesterol levels was $32.94 \%$, which was the highest compared to other groups. Whereas, in the $\mathrm{P}_{3}$ group, the decrease in total blood cholesterol levels was 31.09\%, as showed in table (3). 
Based on the result, the ability of yellow pumpkin extract in reducing total blood cholesterol levels of rats was due to secondary metabolites, such as flavonoids and terpenoids. Flavonoids had a mechanism of action to inhibit the enzyme HMG Co-A reductase ${ }^{4}$.

The mechanism of flavonoids has similarities with the mechanism of action of simvastatin in reducing cholesterol levels. Flavonoids also have a role as antioxidants that act to reduce LDL in the body. Yellow pumpkin contains a flavonoid of $4.433 \mathrm{mg} / \mathrm{mL}$ quercetin. It also contains flavon and flavonols as an antioxidant $^{10}$ and antihyperlipidemic. Flavonoid as antihyperlipidemic includes isoflavones, flavones and flavonols ${ }^{4}$. Flavones groups in yellow pumpkin are viteksin, isoveteksin, krisoeriol and apigenin ${ }^{10}$ as antihyperlidemia ${ }^{4}$. Quercetin and azaleatin are included in flavonols groups in yellow pumpkin extract ${ }^{10}$, having a role as antihyperlipidemic. Apart from flavonoids, terpenoids also have activities to lower total blood cholesterol levels. it has antihypercholesterolemic activity by acting as ligands for PPAR (Peroxisome Proliferator-Activated Receptor) ${ }^{7}$.

\section{CONCLUSION}

Extract of yellow pumpkin (Cucurbita maxima D.) flesh affected the reduction of total cholesterol levels in hyperlipidemic male rats. A $600 \mathrm{mg} / \mathrm{kg} \mathrm{BW/day} \mathrm{dose} \mathrm{could}$ reduce total cholesterol levels compared to a dose of simvastatin $1.8 \mathrm{mg} / \mathrm{kg}$ BW/day. This anti-hypercholesterolemic pharmacological activity was influenced by the content of secondary metabolite compounds in the form of flavonoids and terpenoids in yellow pumpkins.

\section{ACKNOWLEDGMENT}

We would like to thank those who helped and were involved in this research.

\section{REFERENCES}

1. Harikumar, K., Althaf, S. A., Kumar, B, K., Ramunaik, M. \& Suvarna, C. H. (2013). A Review on Hyperlipidemic. International Journal of Novel Trends in Pharmaceutical Sciences, 3(4), pp. 5970.

2. Muchirah, P. N., Waihenya, R., Muya, S., Abubakar, L., Ozwara, H., \& Makokha, A. (2018). Characterization and anti-oxidant activity of Cucurbita maxima Duchesne pulp and seed extracts. The Journal of Phytopharmacology, 7(2), pp. 134-140.

3. Bhise, S. \& Kulkarni, S. (2015) Determination of Antioxidant Activity and Phytochemical Screening of Cucurbita maxima Duch . fruit extracts in non polar to polar solvents. International Journal of PharmTech Research, 8(4), pp. 771-775.

4. Zeka, K., Ruparelia, K., Arroo, R. R. J., Budriesi, R., \& Micucci, M. (2017). Flavonoids and Their Metabolites: Prevention in Cardiovascular Diseases and Diabetes. Disease, 5(3), pp. 1-18.

5. Tenda, P. E., Lenggu, M. Y., \& Ngale, M. S. (2017). Antibacterial Activity Test of Ethanol Extract of Faloak Tree Skin ( Sterculia sp.) On Staphylococcus Aureus Bacteria. Jurnal Info Kesehatan, 15(1), pp. 227-239.

6. Fitriarini, S. \& Rahayuningsih, H. M., (2014) Perbedaan Pengaruh Antara Ekstrak Dan Rebusan Daun Salam (Eugenia polyantha) dalam 
Pencegahan Penurunan Kadar

Kolesterol HDL Pada Tikus Sprague Dawley. Journal of Nutrition College, 3(1), pp. 184-191.

7. Azhari, B., Luliana, S., \& Robiyanto (2017). Uji Aktivitas Antihiperkolesterolemia Ekstrak Air Buah Belimbing Wuluh (Averrhoa bilimbi Linn) Pada Pemodelan Tikus Jantan Galur Wistar Hiperkolesterolemia. Traditional Medicine Journal, 22(1), pp. 57-62.

8. Polat, E. S., Citil, O. B., \& Garip, M. (2013). Fatty acid composition of yolk of nine poultry species kept in their natural environment. Animal Science Papers and Report, 31(4), pp. 363-368.

9. Yin, W., Carballo-Jane, E., McLaren, D. G., Mendoza, V. H., .... (2012). Plasma lipid profi ling across species for the identifi cation of optimal animal models of human dyslipidemia. Journal of Lipid Researchsearch, 53(1), pp. 51-65.

10. Sunnah, I., Erwiyani, A. R., Yunisa, K. O., \& Pratama, N. M. (2020). Skreening Fitokimia Formula Masker Gel Peel-off Nano Ekstrak Daging Labu Kuning ( Cucurbita maxima). Indonesian Journal of Pharmacy and Natural Product, 3(1), pp. 19-24. 